\title{
The Relationship Of The Role Of Parents And Peers To The Occurrence Of Menarche Among Female Students In Smp Negeri 26 Banjarmasin
}

\author{
Novita Dewi Iswandari ${ }^{1 *}$ \\ ${ }^{1}$ AKBID Sari Mulia Banjarmasin, Indonesia \\ *novitadewiiswandari@yahoo.com \\ Imam Santoso ${ }^{2}$ \\ ${ }^{2}$ Health Polytechnic Banjarbaru, Indonesia \\ Imamsantoso165@gmail.com \\ Novia Zuvita Dewi ${ }^{3}$ \\ ${ }^{3}$ STIKES Sari Mulia, Banjarmasin Indonesia \\ noviazude@yahoo.com
}

\begin{abstract}
Objective: To know the relationship of parent and peer role to the occurrence of menarche to female students of SMPN 26 Banjarmasin.

Method: This was an analytical survey using Cross-Sectional approach. The sampling used Quota Sampling technique amounted to 91 respondents. The data collection was done by distributing questionnaires.

Results: Of 91 respondents, 45 students (49.5\%) with menarche had a good category of the role of parents, while 49 students $(53.8 \%)$ had a good category of the role of peers. The result of analysis using Chi Square test showed that there was a relationship between the role of parents and the occurance of menarche with a $\mathrm{p}$ value of 0.005 , meaning the value of $p$ was <value $\alpha(0.05)$. There was a relationship of the role of peer to the occurrence of menarche with a $\mathrm{p}$ value of 0.023 , meaning the value of $\mathrm{p}$ was $<$ value $\alpha$ (0.05).

Conclusion: In general, the good role of parents and peers for adolescents will be able to help children in the face of puberty such as menarche and parents are as a important source of information so that children are not wrong in getting information.
\end{abstract}

Keywords: Menarche, role of parents, junior high school female students, peers.

\section{INTRODUCTION}

Puberty in adolescent girls is marked by the onset of menstruation for the first time (menarche). Menarche is the first menstrual period commonly in age 10-16 years or in early adolescence in the middle of puberty before entering the reproductive period.

Menarche is a natural thing that must be experienced by every normal woman and there is no need to be worried about. However, this will get worse if the teenagers' knowledge about menstruation and 
parent education are very lacking [1].

The results of a study conducted at SD Negeri Kretek Paguyangan, Brebes District with 52 respondents stated that the respondents were ready to face menarche as many as 4 children, and all children (100\%) got information about menarche from their family. The respondents who were not ready to face for menarche were 48 children and most sources of information about menarche were obtained from peer group, i.e., 27 children $(51.92 \%)$ while the rest obtained from family by 9 children $(17.30 \%)[2]$.

Basically, adolescent girls learn about menstruation from their mothers. Nevertheless, not all mothers provide sufficient information to their daughters, and some do not want to talk about it openly. This raises anxiety in children. Children may feel embarrassed and consider menstruating a disease [3].

Based on the preliminary study conducted at SMPN 26 Banjarmasin with discussion on 10 female students, there were 9 students who had experienced menarche at the age of 11 years, where 6 students that had menarche and one who had not experienced menarche admitted to get menarche information from their parents and 4 who had menarche admitted to get information from their peers. They were informed by their parents about the things that should not be done when they had menstruation and how to clean the female organs during menstruation. Those who obtained information from their peers confessed that at the time of menarche their parents were working outside the home so that they asked their peers directly. One student who had not experienced menstruation was afraid and anxious because she had not experienced menarche with her age 13 years. She admitted to have known menarche information from her parents and her peers, but there was a presumption of the peers telling her if she had to go out on a date first so that she would have menarche.

\section{RESEARCH METHODS}

Sampling in this study with quota sampling technique that takes all members of the population as respondents or samples, the number of samples in this study were 91 
people. The method used in this study is an analytic survey, in this study using cross sectional approach. Time of research conducted in April 2015 with a period of one week research. Location of research conducted in SMPN 26 Banjarmasin.

The variables in this study consisted of independent variables, namely the role of parents and peers, while the dependent variable is the incidence of menarche. Instruments in this study using questionnaires, where the questionnaire will be tested the validity to the SMP which has the same characteristics with the place of research, before the distributed to the respondent as a research sample. Analysis of this data using Chi-Square test, with significance value $(\alpha) \quad 0.05$ with computerized system.

\section{RESULT}

1. Table 1. Frequency distribution characteristics currence of menarche

\begin{tabular}{|c|c|c|c|}
\hline No & $\begin{array}{l}\text { Respondents' } \\
\text { characteristic }\end{array}$ & Frequenci & $\begin{array}{l}\text { Percentage } \\
(\%)\end{array}$ \\
\hline \multirow[t]{7}{*}{1} & \multicolumn{3}{|l|}{ Menarche } \\
\hline & - $\quad 12$ years & 29 female & 31,9 \\
\hline & - 13 years & students & 57,3 \\
\hline & - $\quad 14$ years & 52 female & 11,0 \\
\hline & & students & \\
\hline & & 10 female & \\
\hline & & students & \\
\hline \multirow[t]{11}{*}{2} & \multicolumn{3}{|l|}{ Age Menarche } \\
\hline & - 10 years & 7 female & 7,7 \\
\hline & 11 years & students & 28,6 \\
\hline & 12 years & 26 female & 36,3 \\
\hline & 13 years & students & 8,8 \\
\hline & - $\quad 14$ years & 33 female & 2,2 \\
\hline & & students & \\
\hline & & 8 female & \\
\hline & & students & \\
\hline & & 2 female & \\
\hline & & students & \\
\hline
\end{tabular}

Table 2. Univariate analysis

\begin{tabular}{|c|c|c|c|}
\hline No & Variables & Frequency & $\begin{array}{l}\text { Percentage } \\
(\%)\end{array}$ \\
\hline 1 & $\begin{array}{c}\text { Currence of } \\
\text { menarche } \\
-\quad \text { Yes } \\
-\quad \text { No }\end{array}$ & $\begin{array}{l}76 \text { female } \\
\text { students } \\
15 \text { female } \\
\text { students }\end{array}$ & $\begin{array}{l}83,5 \\
16,5\end{array}$ \\
\hline 2 & $\begin{aligned} & \text { The Role of Parents } \\
&- \text { Good } \\
&- \text { Fair } \\
&- \text { Bad }\end{aligned}$ & $\begin{array}{l}48 \text { female } \\
\text { students } \\
38 \text { female } \\
\text { students } \\
5 \text { female } \\
\text { students }\end{array}$ & $\begin{array}{l}52,7 \\
41,8 \\
5,5\end{array}$ \\
\hline 3 & $\begin{aligned} \text { Peers } & \\
- & \text { Good } \\
- & \text { Fair } \\
- & \text { Bad }\end{aligned}$ & $\begin{array}{l}54 \text { female } \\
\text { students } \\
33 \text { female } \\
\text { students } \\
4 \text { female } \\
\text { students }\end{array}$ & $\begin{array}{l}59,8 \\
36,3 \\
4,4\end{array}$ \\
\hline
\end{tabular}


Table 3. The relationship of the parents' role to the occurrence of menarche

\begin{tabular}{|c|c|c|c|c|c|c|}
\hline \multirow{3}{*}{$\begin{array}{c}\text { Parents } \\
\text { 'role }\end{array}$} & \multicolumn{4}{|c|}{ Menarche } & \multicolumn{2}{|r|}{ Total } \\
\hline & \multicolumn{2}{|c|}{ Yes } & \multicolumn{2}{|r|}{ No } & \multirow[t]{2}{*}{$\mathrm{N}$} & \multirow[t]{2}{*}{$\%$} \\
\hline & $\mathrm{N}$ & $\%$ & $\mathrm{~N}$ & $\%$ & & \\
\hline Good & 45 & $49.5 \%$ & 3 & $3.3 \%$ & 48 & $52.7 \%$ \\
\hline Fair & 28 & $30.8 \%$ & 10 & $11.0 \%$ & 38 & $41.8 \%$ \\
\hline $\mathrm{Bad}$ & 3 & $3.3 \%$ & 2 & $2.2 \%$ & 5 & $5.5 \%$ \\
\hline Total & 76 & & 15 & & 91 & \\
\hline
\end{tabular}

Thus, the result of chi Square was $(0.005)<\alpha(0,05)$, so that Ho was rejected and $\mathrm{Ha}$ accepted. It means there was a significant relationship between the parents' role and the occurrence of menarche in female students of SMPN 26 Banjarmasin.

Table 4. The relationship of peers in the occurance of menarche

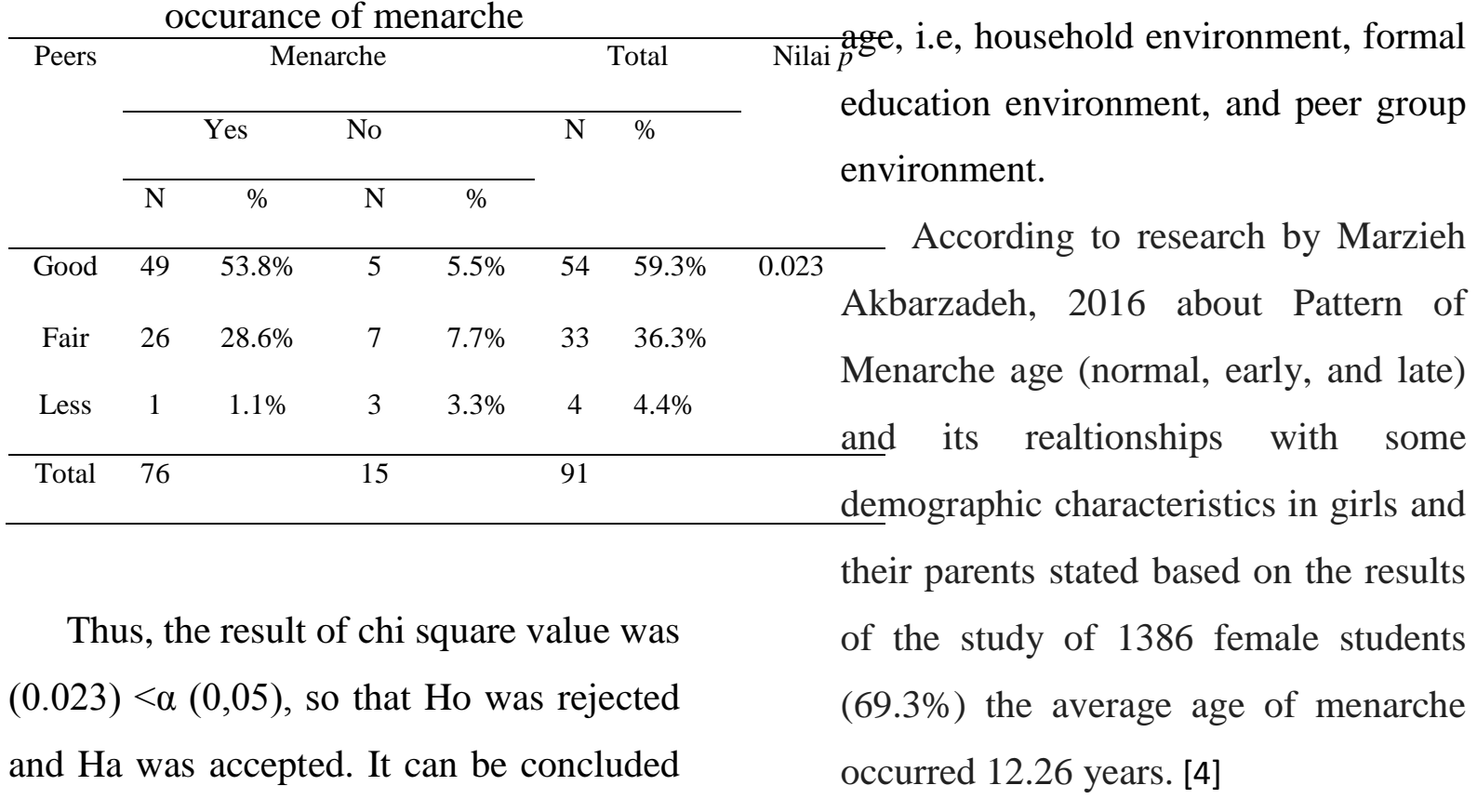

peer role to menarche in the female student of SMPN 26 Banjarmasin.

\section{value IV. DISCUSSION}

1. Menarche

Of 91 female students, there were 0.098 students who had experienced menarche and 15 female students who had not experienced menarche. Of 76 female students who had experienced menarche, 33 female students $(36.3 \%)$ were at the age of 13 years.

The declined menarche age is thought to be related to factors such as genetic, socioeconomics of family, nutritional status, family circumstances, shelter, physical activity, and exposure to adult media, while according to Sujatmiko there are three socio-cultural environments that simultaneously support the acceleration of menarche ge, 1.e, household environment, formal education environment, and peer group According to research by Marzieh . 
2. The Role of Parents

Of 91 students, students with the role of the most parents in good category were 48 female students $(52.7 \%)$ and 49 female students (53.8\%) had parents with the education level of middle school.

The results showed that parents' education could lead to adolescent's increased knowledge, where parents who were highly educated were able to play a good role to provide information, affection and facilities to adolescent's increased knowledge. As in the results of the questionnaire, the respondents answered the questions with the highest scores on the question of parents who told the signs of the first menarche and parents were the first persons to be notified when they experienced menarche. From the results, it was concluded that parents were the ones closest to the childrent. Those who educated children from small at home and who had education and knowledge greatly affected their children. Parents who have a high education will communicate something needed by their children. This situation results in the children's knowledge to be high [5].

3. The Peer's Role

Of 91 students, 49 (53.9\%) female students who had experienced menarche had good category of peer's role.

Social support in the form of emotional support, rewards, information, instrumental, and social networks provided by peers to the friends with menarche can help their friends cope with the feelings of anxiety and fear [6].

4. The relationship of the parents' role to female students in the occurrence of menarche at SMPN 26 Banjarmasin

Based on the results of the study, the respondents who had experienced menarche with the role of parents at good category were 48 respondents $(52.7 \%)$. The result of statistical test showed that there was a significant relationship between the parent's role and the occurrence of menarche with a $\mathrm{p}$ value of $(0.005)<\alpha(0.05)$, so that Ho was rejected and Ha was accepted.

The results of this study were supported by the results of Ezra Ebenezer Soleman's study which showed that information about menstruation is mostly obtained from mother and relatives. If the menstrual event is not accompanied by the provision of clear and true information, it will lead to fear, anxiety and internal conflict. The effect of information on the right menstruation can get rid of the 
myths and wrong information about menstruation [7].

Parents have a very important role in delivering their children into adulthood. Father and mother become the main source of information about puberty to teenagers correctly and trustworthy [8].

Based on a study conducted by Muriyana, parents should earlier provide an explanation about menarche to their daughter, so that the daughther has better understanding and is ready in the face of menarche. According to Suryani and Widyasih (2008), when the menarche event is not accompanied by the correct information, it will arise some psychological disorders, such as dizziness, nausea, or irregular menstruation. [9].

Parents have a big role in providing information about the development of adolescents; therefore, parents, especially mother, are expected to provide support so that adolescents feel comfortable and not afraid to experience development, especially in female adolescents, i.e., experiencing first menstruation (menarche). Knowledge given to adolescents about the first menstruation can be in the form of knowledge about the process of biological menstruation, emotional support, and psychological support [10]. The study of Alma Toromanović, 2015 on the Effect of Family Disintegration on age at menarche based on the research results of the role of the family had the impact of each family stress on the age of menarche, that the menarche age was significantly lower in girls from single mother families, divorced parents, his parents died and where alcoholism was in the family rather than in girls of whole families. Maturation was found earlier in daughters of dysfunctional families, then in intact families after the influence of their homes and relatives [11].

5. The relationship of peers to the occurrence of menarche in SMPN 26 Banjarmasin

Based on the study, the relationship of peers to the occurrence of menarche among female students in SMPN 26 Banjarmasin consisted of good, fair, and bad categories. Based on the results of the study, the respondents who had experienced menarche with the role of peers were included in the good category by 49 respondents (59.3\%). The result of statistical test showed that there was a significant relationship between peer's relationship and the the occurrence of menarche with a $p$ value 
of $(0.023)<\alpha(0.05)$, so that Ho was rejected and Ha was accepted.

The development of adolescent social life is also characterized by the increasing symptoms of peer's influence in their life. Most of the time is spent on connecting or hanging out with their peers. In an investigation, it was found that children related with the peers at $10 \%$ of the time each day at age of 2 years, $20 \%$ at age of 4 years, and over $40 \%$ at age of 7-11 years [8].

Dwi Yati's research, 2015 on the effect of the respondent's presentation of anxiety during the initial test 43 $(100 \%)$ and post test $34(79.1 \%)$. The result of chi square test with $\mathrm{p}$ value $0,000$ ( $\mathrm{p}<0.05)$ means there are significant differences of anxiety before and after peer education. The results of qualitative analysis among adolescents after attending their peer education say they are happy, peer education reduces anxiety, confusion and fear due to increased peer knowledge, providing descriptions and motivations from issues such as discussion, sharing stories and experiences [12].

\section{CONCLUSION}

Based on the results of the study in the research conducted in SMPN 26 Banjarmasin, there is a relationship between the role of parents and the the occurrence of menarche $(\mathrm{p}=0.005)$.

\section{REFERENCES}

[1] Proverawati dan Misaroh.2009 Menarche Menstruasi Pertama Penuh Makna. Yogyakarta : Nuha Medika

[2] Hartati T. 2009. Hubungan Faktor Keluarga dengan Pengetahuan Menstruasi Remaja Putri (Studi SD 2 Losari Brebes) tahun 2009. Tesis : Semarang (accessed 1501-2015)

[3] Llewellyn, Jones, D. 2005. Setiap Wanita: Panduan Terlengkap Tentang Kesehatan, Kebidan dan Kandungan.Delapratasa Publishing

[4] Marzieh Akbarzadeh, Naeimeh Tayebi, Zahra Yazdznpanahi, Shahrzad Yekatatalab, Najaf Zare. Pattern of menarche age (normal, early, and late) and its realtionship with some demographic characteristic in girls and their parents.International jurnal of adolescent medicine and health. Published Online: 2016-0826 | DOI: https://doi.org/10.1515/ ijamh-2016-0048 
[5] Suprapti, Indarwat. 2013. Peran

Orangtua dan Pengetahuan

Remaja tentang Pubertas di

Salahsatu SMP Negeri Boyolali.

Skripsi: Surakarta.

[6] Smet ,bart 2006. Psikologi

Kesehatan. Jakarta : PT .Grasindo

[7] Ezra E,S, Paulina F, 2003,

Konstitusional Psikologi Remaja

Putri yang Telah Mengalami

Menarche di SLTP Negeri 1

Kecamatan Indralaya Kabupaten

Ogan Ilir, Fakultas Kedokteran

Universitas Sriwijaya.

[8] Hurlock, Elizabeth B. 2004.

Psikologi Perkembangan Suatu

Pendekatan Sepanjang Rentan

Kehidupan Edisi Kelima. Jakarta :

Erlangga

[9] Widyasih S. 2008. Hubungan

Sumber-Sumber Informasi dan

Tingkat Pendidikan Orang Tua

Dengan Pengetahuan Pubertas

Remaja SMP Kabupaten Boyolali.

[Skripsi]

[10] Aboyeji, 2005. Jurnal Penelitian

Peran Ibu dalam Perubahan

Remaja saat Mengalami

Menarche.

http://www.ejournal.undip.ac.id/i

ndex.php/psikologi

[11] Alma Toromanavic, Husref

Tahirovic. Effect of family disintegration on age at menarche. Acta Medica $\begin{array}{ll}\text { Academica.2015.44 } & \text { (2).124- }\end{array}$ 134.DOI: 10.5644/ama 2006124.140

[12] Dwi Yati, Irwan T. Rachman, Wahyu Ikka.The Effect of Peer Education to anxiety to teenager in post menarche in sub district Kasihan Bantul, Indonesia. International Journal of Research In Medical Sciences. 2015. Dec:3 (Suppl 1): S10-S18. 